\section{Committee Against Malnutrition}

The Committee against Malnutrition has issued for publication a memorandum which has been sent to the Advisory Committee on Nutrition of the Ministry of Health. The Committee considers that the full application of modern advances in the knowledge of nutrition would effect a general raising of the standard of health comparable to that which followed the lessening of disease by the construction of an adequate system of public sanitation. It is necessary not only to provide food of good quality, in sufficient amounts, but also to ensure the correct relation between the component foodstuffs. This can only be done by allowing an appreciable margin over any minimum standard hitherto formulated : the Committee considers that there is evidence that many lowly paid and unemployed families cannot purchase enough food to allow such a margin. The purchase of foodstuffs of special value will be at the expense of the cheaper energy-producing foodstuffs ; dietary studies have shown that the change over to vitamin-rich food takes place automatically with increasing income. The addition of vitamin concentrates to the diet is deprecated. The Committee recommends that the precise food values of commercial preparations should be published by the Advisory Committee on Nutrition of the Ministry of Health, and that processing and dyeing foodstuffs should be prohibited. The view is put forward that all school children should receive half a pint of milk a day and nursing and expectant mothers at least one pint, with a scale of charges on a fair income basis. The Committee also expresses the opinion that the notion of minimum diets should be condemned.

\section{Vitamin Standards}

AT the request of the Health Organisation of the League of Nations, the Board of Trustees of the United States Pharmacopœia has consented to make generally available the standard cod-liver oils, prepared for use in the United States as secondary standards for vitamins $A$ and $D$. The distribution of these oils will not be made through the national distributing centres as in the case of the primary vitamin standards, but direct to individual users. They may be obtained from Mr. E. Fullerton Cook, Chairman of the Committee of Revision of the U.S. Pharmacopœia, 43rd Street and Woodland Avenue, Philadelphia, Pa., U.S.A. It should be clearly stated whether vitamin A oil or vitamin D oil is required. A charge of 2.50 dollars is made for containers holding 30 c.c. A sum to cover the cost of the quantity required should be sent by international money order with the application. The oils will be sent post paid to their destinations. These reference oils are checked each six months biologically against the international standards by at least six laboratories, and their potency should therefore be increasingly dependable. Secondary standards of vitamins $A$ and $D$ are of considerable importance to British users, as it has not been possible to supply the primary international standards of these vitamins in quantities sufficient to enable them to be used for routine assays.

\section{The Hæmatopoietic Liver Substance}

The Yorkshire Post of July 9 directs attention to the recent isolation by Dr. H. D. Dakin, who is a former student of the Yorkshire College in Leeds, and West, of a substance effective in causing blood regeneration in pernicious anæmia; the paper describing the investigation is published in the Journal of Biological Chemistry, vol. 109 , p. 489 ; 1935. The material is obtained from liver extract by precipitation with Reinecke acid; the precipitate is decomposed with the aid of dimethylaniline and the active principle afterwards purified by salting out with ammonium and magnesium sulphates and sodium chloride. It appears to be of protein nature: on hydrolysis, an aminohexose similar to glucosamine was isolated together with lysine, arginine, glycine, leucine, hydroxyproline and aspartic acid; cruder preparations also contain histidine, glutamic acid and possibly traces of phenylalanine. Pepsin hydrolyses it to a slight extent, erepsin completely though slowly. The compound produces a good reticulocyte response in cases of pernicious anæmia in doses of $80 \mathrm{mgm}$. when given by subcutaneous or intravenous injection. Dakin and West's paper indicates that a distinct advance has been made in the problem of isolating the liver principle active in pernicious anæmia.

\section{Broadcasting and the Jubilee Naval Review}

FEw events of outstanding national interest now take place unaccompanied by a broadcast commentary. The Silver Jubilee review of the Fleet by His Majesty the King provided yet another demonstration of the use and efficiency of the national broadcasting service by distributing an eye-witness account of the scene and action of the review at the actual time of the event. On this occasion, the series of broadcasts was given by two naval officers located at the foretop on board H.M.S. Royal Sovereign, one of the ships taking part in the review, and occupying a very advantageous position from the commentators' point of view. A short-wave portable radiotelephony transmitter installed in the Royal Sovereign was used for the purpose of communicating the commentary to a receiver suitably located at Southsea Castle on the mainland. The signals thus received were transmitted by land-line to Broadcasting House, whence they were distributed in the ordinary way through the National stations. The programmes broadeast included a description of the scene at Spithead on the night preceding the review, with the 160 or so ships of all classes correctly assembled in position. On the actual day of the review, July 16, separate commentaries were arranged to describe the scene when H.M. the King received the Royal Salute, and then proceeded to sail up and down the lines of battleships ; and finally at night a description of the illuminations of the fleet and the firework displays was given from the vantage-point of the Royal Sovereign. Four microphones were employed to pick up the gun salutes, cheers of the ships' crews and other characteristic sounds. As is now usual on such occasions, suitable recordings were made of the programmes to enable these to be repeated later, particularly for the benefit of Empire listeners. 